UDC 615.31:541.64:539.6:617-089.844:615.28

\title{
Chitosan-apatite composites: synthesis and properties
}

\author{
L. F. Sukhodub ${ }^{1}$, L. B. Sukhodub ${ }^{2}$, I. V. Chorna ${ }^{1}$ \\ ${ }^{1}$ Sumy State University \\ 2, Rymskogo-Korsakova., Sumy, Ukraine, 40007 \\ ${ }^{2}$ Mechnikov Institute of Microbiology and Immunology NAMS of Ukraine \\ 14, Pushkinska Str., Kharkiv, Ukraine, 61057 \\ l_sukhodub@yahoo.com
}

\begin{abstract}
The aim of this short review was to discuss applications of a unique biopolymer chitosan in practical medicine, especially for bone tissue engineering. The article highlights the preparation and properties of innovative chitosan-based biomaterials such as CaP-chitosan (CS-CP)-composites and chitosan-alginate (CS-AG)-scaffolds. This paper takes a closer look at the physicochemical properties, spectral characteristics and chemical modifications of the chitosan molecule. The obtained chitosan-apatite composites were analysed using X-ray diffraction to verify the crystalline nature of their structures. It was observed that the addition of chitosan to the composite material reduces apatite crystallinity. Besides, an accent was made on antibacterial properties of chitosan, the use of chitosan nanoparticles to produce nanofibers and controlled drug delivery systems.
\end{abstract}

Ke y w o r d s: chitosan, hydroxyapatite, biocomposites, X-ray diffraction.

\section{Introduction}

Over the last years, chitosan (CS) has attracted a great interest of scientists as functional polymeric material because of its remarkable intrinsic properties: biodegradability, biocompatibility, nontoxicity, antibacterial activity, mucoadhesive, analgesic and haemostatic properties [1-3]. Chitosan is a linear, semi-crystalline polysaccharide composed of $(1 \rightarrow 4)$-2-acetamido-2-deoxy- $\beta$-D-glucan ( $\mathrm{N}$-acetyl D-glucosamine) and $(1 \rightarrow 4)$-2-amino-2-deoxy- $\beta$-Dglucan (D-glucosamine) units [1, 4-6]. Chitosan can be easily obtained from a natural polymer chitin after its partial deacetylation by chemical hydrolysis under severe alkaline conditions or by enzymatic hydrolysis [7, 8]. Chitosan is well tolerated by living tissues, including the skin, ocular membranes, the nasal epithelium. A low or no toxicity of chitosan compared with other natural polysaccharides has been demonstrated by in vivo toxicity studies [9].
Some studies showed that chitosan, as an immune adjuvant, could effectively promote the local immune response and enhance antigen presentation [10]. The combination of CS with different materials, such as hydroxyapatite (HA), is very promising, especially for orthopedics and traumatology [11]. All these features make chitosan an outstanding candidate for biomedical applications.

\section{Physical and chemical properties of chitosan}

Chitosan as the product of partial deacetylation of chitin contains five types of active functional groups: primary amine groups at the C-2 position of each deacetylated structural unit, secondary amide groups, ether groups of polysaccharide main chain as well as both primary and secondary hydroxyl groups at the C-6 and C-3 positions, respectively (Fig. 1).

The molecular weight (MW) of CS is in the range of 300 to $1000 \mathrm{kDa}$ and it depends on the source and the method used for obtaining CS. Degree of CS

(C) 2016 L. F. Sukhodub et al.; Published by the Institute of Molecular Biology and Genetics, NAS of Ukraine on behalf of Biopolymers and Cell. This is an Open Access article distributed under the terms of the Creative Commons Attribution License (http://creativecommons.org/licenses/by/4.0/), which permits unrestricted reuse, distribution, and reproduction in any medium, provided the original work is properly cited 

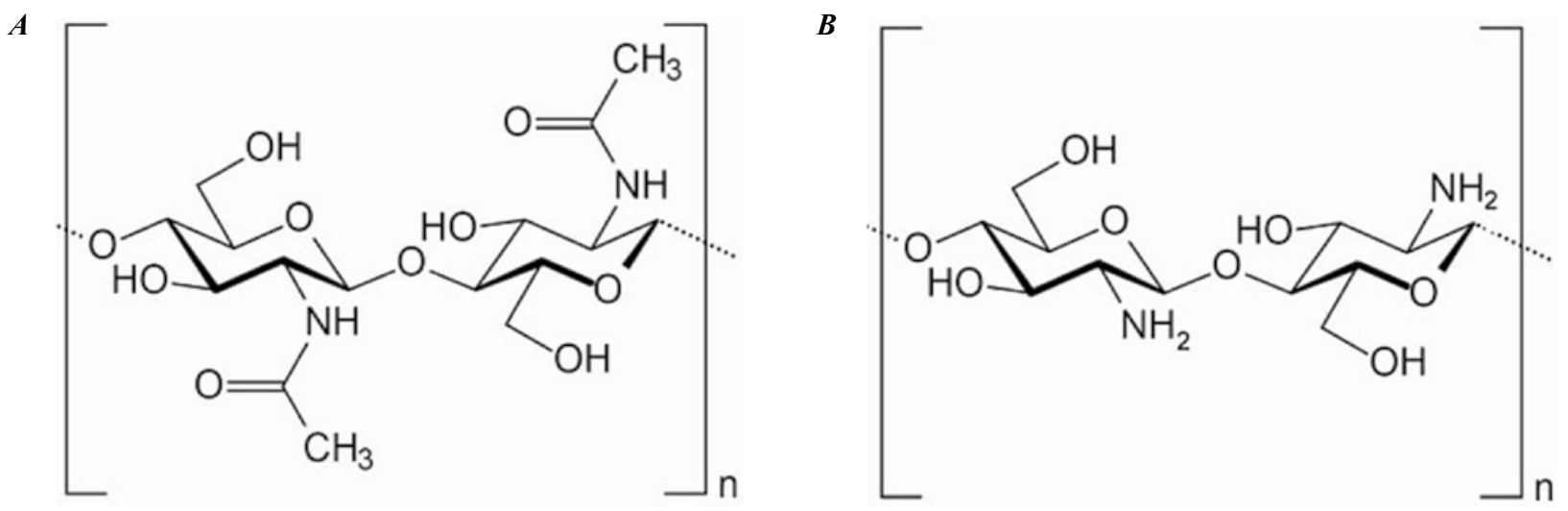

Fig. 1. The structural formula of chitin $(A)$ and chitosan $(B)$

deacetylation (DD) (N- acetylglucosamine / glucosamine) may vary from 30 to $95 \%$. The higher DD of $\mathrm{CS}$, the greater the quantity of protonated amino groups in the polymer and, correspondingly, the higher the amount of charge on the macromolecule. In crystalline form, $\mathrm{CS}$ is insoluble in aqueous solutions with $\mathrm{pH}>7$ whereas in dilute acids $(\mathrm{pH}<6)$ it becomes soluble due to protonation of $\mathrm{NH}_{2}$ groups [5]. Chitosan's primary amines confer important material properties. At low $\mathrm{pH}$, the amines are protonated making chitosan a cationic polyelectrolyte. In protonated form, the amines allow connection through electrostatic interactions [12]. Due to its amino groups, chitosan can form bonds with a wide variety of organic and inorganic molecules, such as lipids, proteins, DNA and some negatively charged synthetic polymers [13-16]. At high $\mathrm{pH}$, the amines are deprotonated and chitosan undergoes a transition from a soluble cationic polyelectrolyte to an insoluble polymer. Insolubility of chitosan in water means that the intermolecular interactions between macromolecules exceed the interactions in the system of "chitosan-water molecules". Importantly, this $\mathrm{pH}$-responsive switch is near neutrality (chitosan's apparent $\mathrm{pKa}$ has been reported to range between 6 and 7) $[17,18]$ suggesting chitosan as a biologically-derived

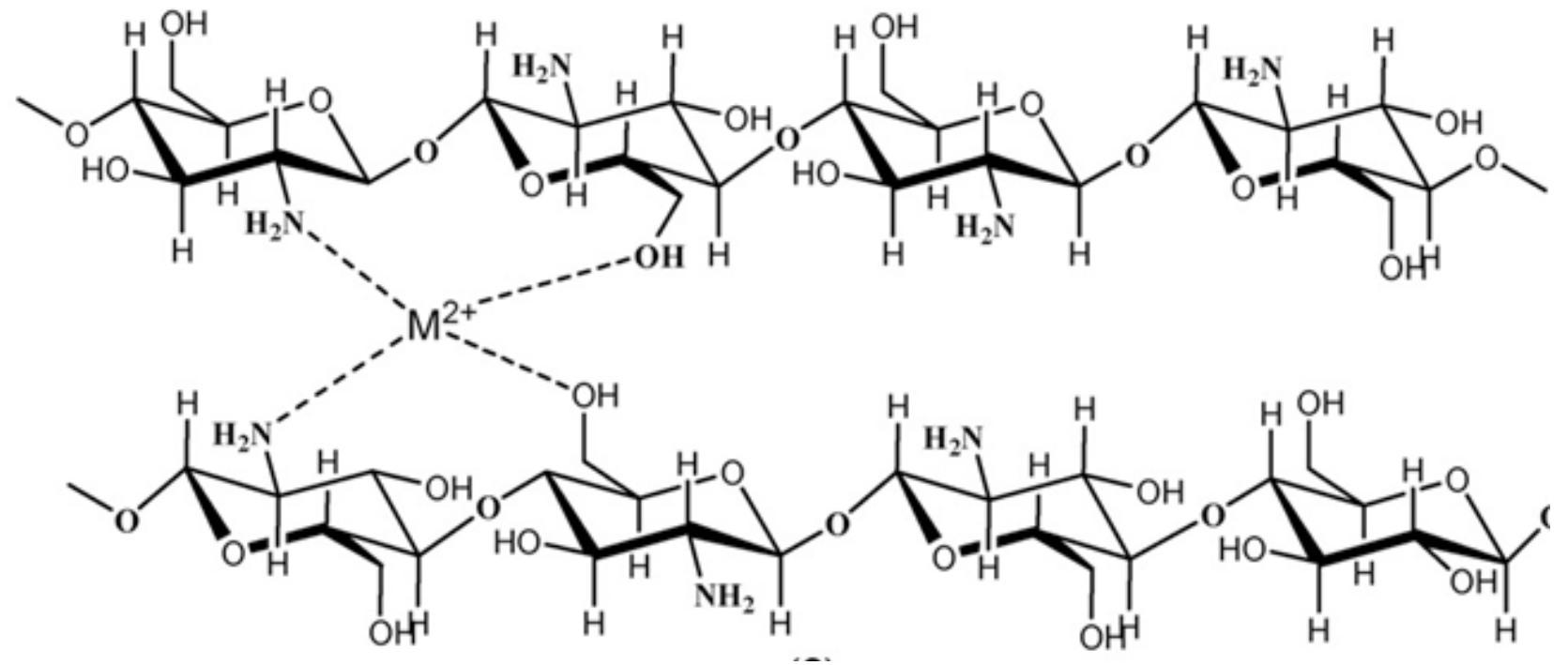

Fig. 2. Schematic representation of the metal-chitosan complexation [22] 
stimuli-responsive polymer for medical applications (e.g., injectable matrices) [19]. There are well known the nucleophilic properties of the amines that allow connections through covalent linkages that can be formed through a range of coupling chemistries [20]. Chitosan's metal binding properties [21] allow connections through chelation mechanisms. Fig. 2 illustrates the structural chemical formula of two strands of chitosan and the "cross-linking" mechanism caused by the divalent metal ion [22].

Micro/nanoparticles and hydrogels are widely used in the design of chitosan-based therapeutic systems [4]. The cationic nature of CS provides the electrostatic interaction with quantivalent linear anionic polysaccharides (glycosaminoglycans (GAG), proteoglycans etc.). This factor is very important because of a large number of growth factors and other proteins bound to GAG, that is why the formation of GAG-CS complexes provides maintenance and accumulation of these necessary biopolymers in vivo. Thus, chitosan based scaffolds deliver growth factors in a controlled fashion to promote the in-growth and biosynthetic ability of chondrocytes [4]. Under the action of cellular enzymes, especially lysozyme, CS degraded depending on the degree of crystallinity and deacetylation [6]. Hence these properties must be necessarily taken into account at creating chitosan based implants. Also it should be noted that the CS hydrogel composite is able to form a porous structure using, for example, lyophilization technology ("freeze-drying"). A pore size in the CS hydrogel composite depends on speed of freezing. The degree of porosity and pore orientation significantly affect the mechanical properties of the implant. Another property of CS is its internal antibacterial ability [23-25].

\section{Chitosan in bone tissue engineering}

Tissue engineering (TE) is an interdisciplinary area that contains both a basic knowledge of life sciences and engineering to create biologically compatible, biodegradable scaffolds (matrices) in different forms (powder, microcapsules, gels, films, etc.) for a wide use in nanomedicine. Systems for the controlled drug delivery by using chitosan and its derivatives are of huge interest [4]. Chitosan is widely used in bone tissue engineering because of its ability to promote a cell growth and the formation of mineral matrix by osteoblasts [26]. Biocompatibility of chitosan minimizes the local inflammation, and its conversion into a porous structure contributes to osteoconductivity [27]. The Chitosan - Calcium Phosphate composites (CS-CP) were the subject of intensive study in the world [28-31].

\section{CS-CP composites}

Biomaterials that mimic the structure and composition of bone tissues at the nanoscale level are extremely important for the development of bone tissue engineering applications [32]. CS-CP composites have certain advantages compared to other similar structures. Thus, during the resorption, the degradation products of chitosan and calcium phosphate (calcium ions, phosphates, glycosamines, etc.) are naturally metabolized and do not induce the increasing calcium and phosphorus concentrations in urine, serum or internal organs. A composite material contains both the macro- and micropores and nano-sized crystals of HA. This promotes an increase in the reactive surface and material osteoconductive activity. Similar 3D-macroporous ceramics pierced by chitosan grid have better mechanical properties [33, 34]; therefore, there is a perspective of the CS-CP composites future use in the clinic. The main advantages of CS-CP biomaterials are: structural organization, which is close to the structure of natural bone, biocompatibility, biodegradation, macro- and microporosity, regulation of resorption rate, immobilization of drugs, antibacterial action, simplicity of flowsheet synthesis, low cost.

Among a wide range of calcium phosphates hydroxyapatite (HA), $\mathrm{Ca}_{10}\left(\mathrm{PO}_{4}\right)_{6}(\mathrm{OH})_{2}$ is a widely used material for biomedical application in dentistry and orthopedy due to the excellent bioactivity, biocompatibility and osteoconductivity [31, 35]. However, the migration of HA powder from implanted sites and bone defects is really a big problem. Therefore, organic compounds in nanocompo- 
sites are promising for improving weak mechanical properties of HA [36].

The CS-HA composites have been recently synthesized in our laboratory. For this aim the chitosan macromolecules ( MW $500 \mathrm{kDa}, 200 \mathrm{kDa}, 39 \mathrm{kDa}$ ) with DD $85 \%$ were supplied by the "Bioprogress" (Moskow, Russia). Calcium acetate $\mathrm{Ca}\left(\mathrm{CH}_{3} \mathrm{COO}\right)_{2}$, sodium dihydrogen phosphate $\mathrm{NaH}_{2} \mathrm{PO}_{4}$, and sodium hydroxide $(\mathrm{NaOH})$ were of analytical grade and supplied by "Merck". An influence of the chitosan's molecular weight and various ways of the synthesis on obtaining the CS-HA composite structure have been studied. Calcium acetate was used as the $0.167 \mathrm{M}$ solution in $1 \% \mathrm{CH}_{3} \mathrm{COOH}$ (first way of synthesis) or was added in solid state to chitosan solution in $1 \% \mathrm{CH}_{3} \mathrm{COOH}$ (second way of synthesis).

By the first way of synthesis $0.8 \mathrm{~g}$ of chitosan powder with certain MW were added to $20 \mathrm{~mL}$ of the $0.167 \mathrm{M}\left(\mathrm{CH}_{3} \mathrm{COO}\right)_{2} \mathrm{Ca}$ stock solution in $1 \mathrm{w} \%$ $\mathrm{CH}_{3} \mathrm{COOH}$. The final chitosan concentration in the reaction mixture was $0.4 \mathrm{w} \%$. The calcium acetatechitosan solution was stirred in a shaker (160 rpm) for $1.5 \mathrm{~h}$ at $37{ }^{\circ} \mathrm{C}$, then $20 \mathrm{~mL}$ of $0.1 \mathrm{M} \mathrm{NaH}_{2} \mathrm{PO}_{4}$ solution were added gradually to the above mixture. The $\mathrm{pH}$ value was adjusted to 11.8 by using $10 \mathrm{M}$ $\mathrm{NaOH}$ solution. The obtained suspension was aged for 5 days at $22{ }^{\circ} \mathrm{C}$, then washed thoroughly with deionized water to $\mathrm{pH} 7.4$. Finally, the precipitate was separated by centrifuging the suspension. For the analysis the product was dried at $37{ }^{\circ} \mathrm{C}$ and annealed for $1 \mathrm{~h}$ at $900{ }^{\circ} \mathrm{C}$. The second way of synthesis was provided by addition of solid $\left(\mathrm{CH}_{3} \mathrm{COO}\right)_{2} \mathrm{Ca}$ ( $0.526 \mathrm{~g}$ ) to the $20 \mathrm{~mL}$ of the $0.4 \mathrm{w} \%$ chitosan solution in $1 \% \mathrm{CH}_{3} \mathrm{COOH}$. The calcium acetate-chitosan solution was stirred in a shaker (160 rpm) for $1.5 \mathrm{~h}$ at $37^{\circ} \mathrm{C}$, after which $20 \mathrm{~mL}$ of $0.1 \mathrm{M} \mathrm{NaH}_{2} \mathrm{PO}_{4}$ solution were added gradually to the above mixture. The $\mathrm{pH}$ value of solution (about 11.0) was corrected by using $10 \mathrm{M} \mathrm{NaOH}$ solution. A white precipitate was observed after the phosphate solution addition at both ways of synthesis. It was associated with the hydroxyapatite formation. Both suspensions were aged for 5 days at $22{ }^{\circ} \mathrm{C}$, then washed thoroughly with deionized water to obtain solution of $\mathrm{pH} 7.4$.
Finally, the precipitate was separated by centrifuging the suspension. For the analysis the product was dried at $37{ }^{\circ} \mathrm{C}$ and annealed for $1 \mathrm{~h}$ at $900{ }^{\circ} \mathrm{C}$. The Obtained composites consisted of $80 \mathrm{w} \%$ of HA and $20 \mathrm{w} \%$ of CS.

The crystallinity and structure of precipitates were examined using an X-ray diffractometer DRON-3 ("Burevestnik", Russia) connected to a computeraided system for the experiment control and data processing. The Ni-filtered $\mathrm{CuK}_{\alpha}$ radiation (wavelength $0.154 \mathrm{~nm}$ ) with a conventional BraggBrentano $\theta-2 \theta$ geometry was used. The current and voltage of X-ray tube were $20 \mathrm{~mA}$ and $40 \mathrm{kV}$ respectively. The samples were tested in a continuous mode in the range $10^{\circ}$ to $60^{\circ}$ at a rate $2.0^{\circ} / \mathrm{min}$ with $2 \theta$-angles. The samples phase composition was determined and crystallite size calculated. The average crystallite size $(\mathrm{L})$ and strain $(\varepsilon)$ were calculated in the $\left[\begin{array}{lll}0 & 0 & c\end{array}\right]$ crystal direction using XRD data by Scherrer equation [37]. The crystalline phases were identified by comparing the experimental XRD patterns to the standards compiled by the Joint Committee on Powder Diffraction and Standards (JCPDS cards). The formation of crystalline HA phase occurs in both the presence and the absence of polymer, independently from chitosan MW and synthesis way. The existence of $2 \theta$ peaks at approximately $26^{\circ}$, and $31.9^{\circ}$ corresponding to the (002) and (211) diffraction planes confirms the formation of HA phase in products [36]. Taking into account the broadening of each peak in XRD spectra, mean crystallite sizes for examined samples were calculated using Scherrer equation and approximation method (Table 1).

As can be assumed from the Table 1, $20 \mathrm{w} \%$ of chitosan in material composition did not decrease significantly crystallite sizes of HA-CS samples compared to HA sample. The changes in the polymer molecular weight and the way of synthesis had no observable effect on the peaks positions and/or their intensity. However, the strain in $\left[\begin{array}{lll}0 & 0 & \mathrm{c}\end{array}\right]$ direction increased for all HA-CS composite samples indicating significant defects in the hydroxyapatite crystal structure caused by the presence of the polymer. 
Table 1. Structure characteristics of hydroxyapatite nanocrystals in dried at $37^{\circ} \mathrm{C}$ HA-CS nanocomposites

\begin{tabular}{|c|c|c|c|c|}
\hline \multirow[b]{2}{*}{ Sample } & \multirow{2}{*}{$\begin{array}{l}\text { Miller } \\
\text { Indices }\end{array}$} & \multirow{2}{*}{$\begin{array}{l}\text { Crystallite } \\
\text { sizes by } \\
\text { Scherrer, nm }\end{array}$} & \multicolumn{2}{|c|}{ Approximation method } \\
\hline & & & $\begin{array}{l}\text { Crystallite } \\
\text { sizes, nm }\end{array}$ & $\begin{array}{c}\text { Strain, } \\
\cdot 10^{3}\end{array}$ \\
\hline & $\left(\begin{array}{lll}0 & 0 & 2\end{array}\right)$ & 22.8 & 02 & 0 \\
\hline 11A & $\left(\begin{array}{lll}0 & 0 & 4\end{array}\right)$ & 22.8 & 22.0 & 0.005 \\
\hline $\mathrm{HA} / \mathrm{CS}$ & $\left(\begin{array}{lll}0 & 0 & 2\end{array}\right)$ & 21.7 & 515 & 097 \\
\hline $500(1)$ & $\left(\begin{array}{lll}0 & 0 & 4\end{array}\right)$ & 22 & 21.5 & 0.091 \\
\hline $\mathrm{HA} / \mathrm{CS}$ & $\left(\begin{array}{lll}0 & 0 & 2\end{array}\right)$ & 19.6 & 21 & 7 \\
\hline $500(2)$ & $\left(\begin{array}{lll}0 & 0 & 4\end{array}\right)$ & 18.2 & & 0.71 \\
\hline $\mathrm{HA} / \mathrm{CS}$ & $\left(\begin{array}{lll}0 & 0 & 2\end{array}\right)$ & 18.3 & 178 & 7ר \\
\hline $200(1)$ & $\left(\begin{array}{lll}0 & 0 & 4\end{array}\right)$ & 19 & 17.0 & 0.21 \\
\hline $\mathrm{HA} / \mathrm{CS}$ & $\left(\begin{array}{lll}0 & 0 & 2\end{array}\right)$ & 19 & 10 & $0 ?$ \\
\hline $200(2)$ & $\left(\begin{array}{lll}0 & 0 & 4\end{array}\right)$ & 19.7 & & \\
\hline $\mathrm{HA} / \mathrm{CS}$ & $\left(\begin{array}{lll}0 & 0 & 2\end{array}\right)$ & 18.2 & 217 & 152 \\
\hline $39(1)$ & $\left(\begin{array}{lll}0 & 0 & 4\end{array}\right)$ & 15.6 & 21.1 & 1.53 \\
\hline $\mathrm{HA} / \mathrm{CS}$ & $\left(\begin{array}{lll}0 & 0 & 2\end{array}\right)$ & 21.6 & 7 & ( 240 \\
\hline $39(2)$ & $\left(\begin{array}{lll}0 & 0 & 4\end{array}\right)$ & 22.6 & 20.1 & 0.342 \\
\hline
\end{tabular}

To evaluate the functional groups of CS, HA and synthesized composite HA-CS (Fig. 3), the FTIR analysis was performed by the instrument "Thermo Nicolet Nexus 470 ESP" (Minsk Technological University, Belarus). The sample for spectral analysis was prepared in a traditional way: a small amount of the preparation (synthesized composite powder) was mixed with $\mathrm{KBr}$ in the ratio 1:200 in an agate mortar while grinding. From the obtained mixtures corresponding tablets were prepared in press-forms of stainless steel under hydraulic pressure. Transmission spectrum was obtained in the frequency range of $400-5000 \mathrm{~cm}^{-1}$ with a spectral resolution of $0.125 \mathrm{~cm}^{-1}$.

FTIR-spectrum of CS(c) shows characteristic peaks of amide I at $1651 \mathrm{~cm}^{-1}$ (-C=O stretching), amide III at $1378 \mathrm{~cm}^{-1}(\mathrm{C}-\mathrm{N}$ stretching coupled with $\mathrm{NH}$ in plane deformation), $\mathrm{CH}_{2}$ wagging coupled with $\mathrm{OH}$ in plane deformation at $1324 \mathrm{~cm}^{-1}$. The peak at $1598 \mathrm{~cm}^{-1}$ belongs to the bending vibra-

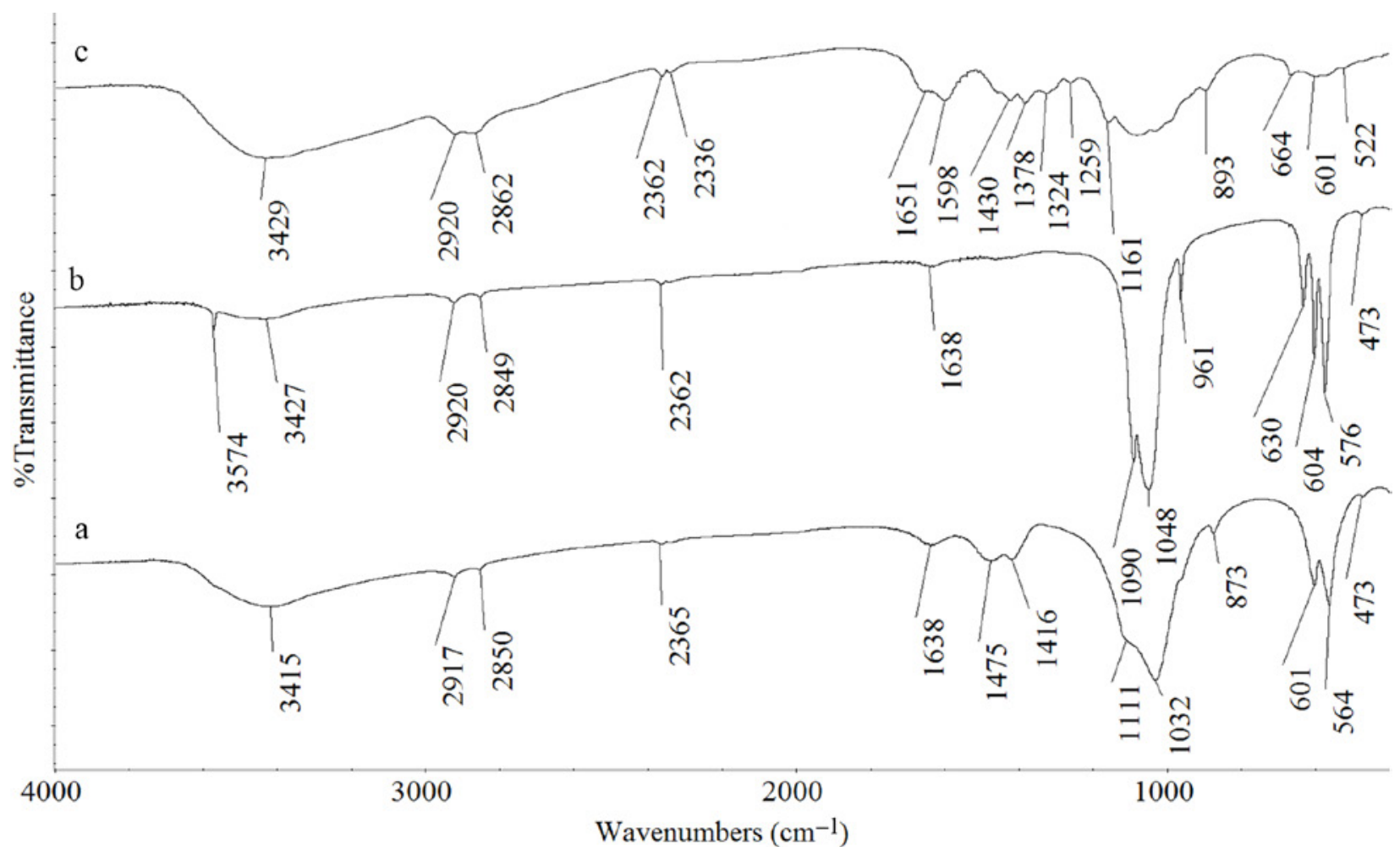

Fig. 3. FTIR-spectra of a) HA-CS nanocomposite (down), b) HA, sintered at $900{ }^{\circ} \mathrm{C}$ (middle), c) CS with MW $500 \mathrm{kDa}$ (top) 
tions of the $\mathrm{N}-\mathrm{H}$ and $\mathrm{C}-\mathrm{N}$ (amide II band). Peaks at 1430 belong to the $\mathrm{N}-\mathrm{H}$ stretching of the amide and ether bonds [38]. The vibration band about $1029 \mathrm{~cm}^{-1}-1077 \mathrm{~cm}^{-1}$ indicates the $\mathrm{C}-\mathrm{O}$ stretching vibration in the primary and secondary hydroxyl groups in chitosan $[39,40]$, wide band $\left(3429 \mathrm{~cm}^{-1}\right)$ is attributed to $-\mathrm{OH}$ stretching and $-\mathrm{NH}_{2}$ asymmetric stretching vibrations [41], the peak at $2868 \mathrm{~cm}^{-1}$ is caused by $-\mathrm{CH}_{2}$-stretching vibrations [42].

FTIR-spectrum of CS (c) shows characteristic bands of amide I (the main contribution of $\mathrm{C}=\mathrm{O}$ stretching) at $1651 \mathrm{~cm}^{-1}$ and amide II (the main contribution of $\mathrm{N}-\mathrm{H}$ bending) together with $\mathrm{N}-\mathrm{H}$ bending vibration of primary amine groups at $1598 \mathrm{~cm}^{-1}$. Three bands at $\sim 1450,1430$ and $1378 \mathrm{~cm}^{-1}$ belong to $\mathrm{C}-\mathrm{H}$ asymmetric and symmetric bending vibrations of methyl and methylene groups. The band of $-\mathrm{CH}_{2}$ wagging coupled with -OH in plane deformation appears at $1324 \mathrm{~cm}^{-1}$. Some vibration bands in a region of $1200-1000 \mathrm{~cm}^{-1}$ with the main peak at $1161 \mathrm{~cm}^{-1}$ indicate asymmetric and symmetric $\mathrm{C}-\mathrm{O}-\mathrm{C}$ and $\mathrm{C}-\mathrm{O}$ stretching vibrations of $\mathrm{CS}$ ether and hydroxyl groups. The $\mathrm{O}-\mathrm{H}$ and $\mathrm{N}-\mathrm{H}$ stretching vibrations of hydroxyl, amide and amine groups of CS appear in FTIR spectrum by a wide band with maximum at $3429 \mathrm{~cm}^{-1}$, whereas $\mathrm{C}-\mathrm{H}$ stretching of $-\mathrm{CH}_{2}$ - and $\mathrm{CH}_{3}$ groups is revealed by two overlapped bands at 2920 and $2862 \mathrm{~cm}^{-1}$.

Pure HA (b) shows a vibration band around $3427 \mathrm{~cm}^{-1}$ and peak at $630 \mathrm{~cm}^{-1}$ corresponding to stretching vibration of the hydroxyl group [43]. The characteristic peaks at $576 \mathrm{~cm}^{-1}, 604 \mathrm{~cm}^{-1}, 961 \mathrm{~cm}^{-1}$, $1048 \mathrm{~cm}^{-1}$ and $1090 \mathrm{~cm}^{-1}$ are due to the bending and stretching modes of $\mathrm{P}-\mathrm{O}$ vibrations in the phosphate network [44, 45].

In the HA-CS spectrum (a) the protonation of chitosan amine functionalities is suggested by the presence of the band, attributed to $\mathrm{NH}_{3}{ }^{+}$groups, namely the bending vibration at $1475 \mathrm{~cm}^{-1}$. This is evidently conditioned by the formation of electrostatic bonds with HA. Also the low-frequency shift of the amide I band up to $1638 \mathrm{~cm}^{-1}$ is observed, thus pointing out the participation of carbonyls of CS amide groups in hydrogen bonding with hydroxyl groups of HA. It was observed the disappearance of the vibration band in HA-CS spectrum (a) at $1324 \mathrm{~cm}^{-1}$ that may indicate partial phosphorylation of hydroxyl groups in CS with the feather formation of calcium phosphates. The wide band indicated the $\mathrm{C}-\mathrm{O}-\mathrm{C}$ and $\mathrm{C}-\mathrm{O}$ stretching vibrations in the ether; the primary and secondary hydroxyl groups in CS spectrum (c) were present as the vibration band with peak at $1032 \mathrm{~cm}^{-1}$ in the spectrum of HA-CS (a). These changes may be attributed to the formation of hydrogen bonds with participation of ether and/or $-\mathrm{OH}$ groups in HA and CS. Additionally, the vibration bands at $960 \mathrm{~cm}^{-1}$ and $630 \mathrm{~cm}^{-1}$, belonging to the phosphate- and hydroxyl- groups in HA (b) were absent in the HA-CS spectrum. All these facts confirm molecular interactions between $\mathrm{CS}$ and HA in the HA-CS composite.

\section{Chitosan-alginate-hydroxyapatite polyelec- trolyte composites}

The chitosan- and sodium alginate (AG)-based scaffolds have been widely used as biomaterials in tissue engineering. Freeze-drying, also known as lyophilization, has been used for the fabrication of polymerbased hydrogels. The porous scaffolds composed of $\mathrm{AG}$ and CS have been fabricated by the formation of a polyelectrolyte complex (PEC) between macromolecules of both polymers [46]. They perform a 3D-grid with uniformly distributed and interconnected pores. Two technologies of the scaffold formation are proposed in this paper. According to the first, the uncrosslinked alginate scaffold is formed from $4 \mathrm{w} \%$ AG solution using the "freeze-drying" technology. Next, it undergoes some crosslinking using $1 \mathrm{w} \% \mathrm{CaCl}_{2}$. By the second technology, the alginate scaffold was immerged into $2 \mathrm{w} \% \mathrm{CS}$ solution or the CS-HA composite acetic acid aqueous solution. In this case the pores of the alginate scaffolds were filled with chitosan solution. These samples were frozen at $-40{ }^{\circ} \mathrm{C}$ and lyophilized. Finally, the samples were additionally crosslinked with $\mathrm{CaCl}_{2}$ solution.

Chitosan-alginate (CS-AG)-scaffolds exhibit better mechanical properties and thermostability than 
AG-scaffold, crosslinked with calcium ions only. The main reasons for the mechanical strength improvement of crosslinked scaffold could be strong ionic interactions. In the $\mathrm{Ca}^{2+}$ crosslinked $\mathrm{AG}$ scaffold the mechanical strength is enhanced because $\mathrm{Ca}^{2+}$ is characterized by strong ionic interaction with $\mathrm{COO}^{-}$in an alginate chain. For CS-AG PEC scaffold the strong interaction exists between $\mathrm{NH}_{3}{ }^{+}$groups in $\mathrm{CS}$ and $\mathrm{COO}^{-}$groups in alginate (Fig. 4). Additionally, a decrease of porosity for crosslinked scaffold is another factor enhancing the mechanical strength.

Considering the participation of chitosan in PEC, it should be noted a series of studies of chitosan complexes with DNA, glycosaminoglycans, chondroitin sulfate, hyaluronic acid, heparin, carboxymethyl cellulose, pectin and proteins such as gelatin, albumin, collagen and keratin [47-52]. The stability of such complexes depends on the charge density, solvent, ionic strength, $\mathrm{pH}$ and temperature [46]. The Chitosan-, alginate- and hydroxyapatite-based scaffolds (with a ratio of $1: 1: 1$ ) were recently synthesized in our laboratory using our own flowsheet. Such precursors were used for the synthesis: chitosan (MW 500 kDa, DD 80\%, "Bioprogress", Moscow), sodium alginate (E401), sodium hydrogen phosphate $\left(\mathrm{Na}_{2} \mathrm{HPO}_{4}\right)$ and calcium acetate $\left(\mathrm{CH}_{3} \mathrm{COO}\right)_{2} \mathrm{Ca} \cdot \mathrm{H}_{2} \mathrm{O}$ (China). $500 \mathrm{ml}$ of chitosan solution $(2 \mathrm{~g} / 1$ in $1 \mathrm{w} \%$ acetic acid) were gradually added to $0.1 \mathrm{M}$ calcium acetate $(100 \mathrm{ml}) ; 1 \mathrm{~g}$ of sodium alginate powder was dissolved in $0.1 \mathrm{M}$ sodi- um hydrogen phosphate $(60 \mathrm{ml})$. Two obtained solutions were mixed and stirred in a shaker $(160 \mathrm{rpm})$ at $37{ }^{\circ} \mathrm{C}$ for $5 \mathrm{~h}$. $\mathrm{pH}$ was adjusted with $10 \mathrm{M} \mathrm{NaOH}$ solution to 11.0. Additionally the mixture was stirred by ultrasound, heated at $80{ }^{\circ} \mathrm{C}$ for $10 \mathrm{~min}$ and aged for $48 \mathrm{~h}$ for the HA nucleation. The obtained product was washed with the deionized water to $\mathrm{pH}$ 7.0-7.4 with subsequent freezing and vacuum drying ("freeze-drying") at $-150{ }^{\circ} \mathrm{C}$ during $16 \mathrm{~h}$. As a result, the porous HA-CS-AG-scaffold with a ratio of components 1:1:1 was obtained. The polymer amounts for the synthesis might be calculated to obtain the product with required component proportions. The cation-anionic interactions between macromolecules of CS and AG are the main driving force in the creation and stabilization of the biopolymer scaffolds [31].

\section{X-ray structure analysis of apatite-biopoly- mer composites}

Recently the usage of materials in the form of hydrogels has become increasingly popular. The structure of the polymer chains that form a three-dimensional net of gel enables immobilization and sufficient content of water, biological fluids or drugs $[53,54]$. We investigated the composite materials that consisted of the polymer matrix and inorganic filler and to some extent modeled a bone. As the polymer matrix, chitosan was used in the sample 1 and sodium alginate - in the sample 2.

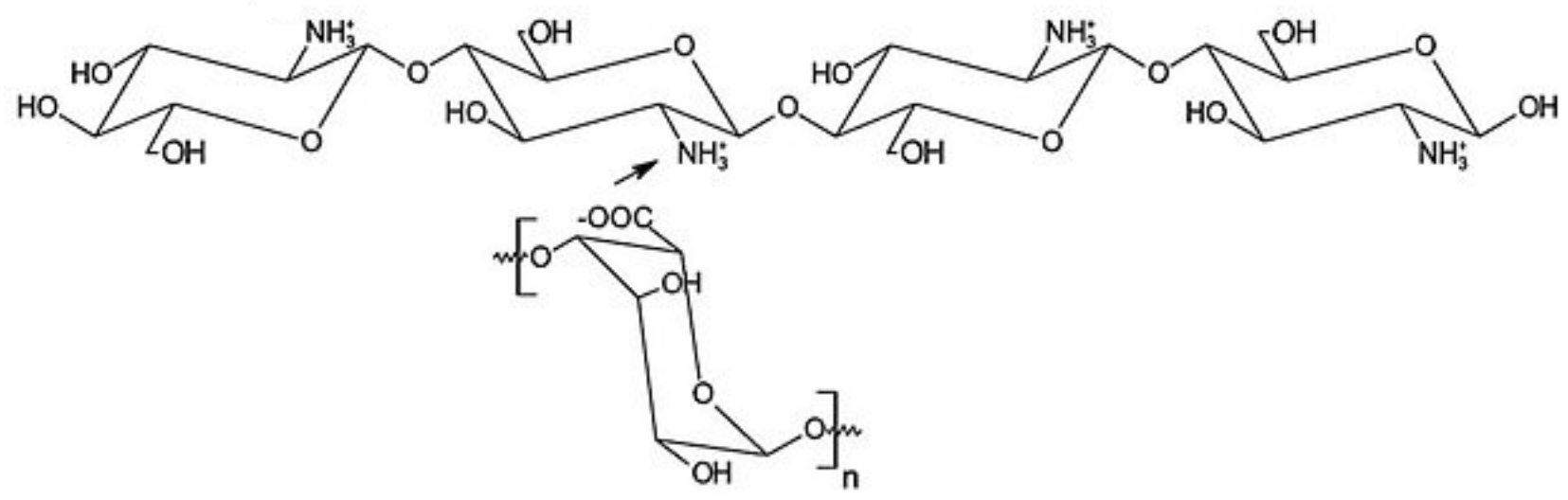

Fig. 4. Chemical structures of CS (top) and AG (down) and the scheme of their interaction 
Sample N 1: HA-CS composite. The HA-CS composite was synthesized by wet chemistry. Two solutions were prepared for the synthesis: 1) $100 \mathrm{~mL}$ [of] $0.1 \mathrm{M} \mathrm{CaCl}_{2}, \mathrm{pH}$ was adjusted up to 11.0 by addition of $10 \mathrm{M} \mathrm{NaOH}$ solution; 2) chitosan (MW 39 $\mathrm{kDa})$ was dissolved in $100 \mathrm{ml}$ of $0.06 \mathrm{M} \mathrm{H}_{3} \mathrm{PO}_{4}$ in the amount, which provides chitosan concentration in the final material from 10 to $40 \mathrm{w} \%$. The second solution was added drop by drop to the first one followed with mixing and heating at $60{ }^{\circ} \mathrm{C}$ during $10 \mathrm{~min}$. The $\mathrm{pH}$ value was adjusted by $\mathrm{NaOH}$ addition to 7.4. After aging for $24 \mathrm{~h}$ the resulting suspension was washed with distilled water and centrifuged. The degree of moisture in the obtained gel ranged from 70 to $88 \mathrm{w} \%$. The composition of solids was: HA from 60 to $90 \mathrm{w} \%$, CS from 10 to $40 \mathrm{w} \%$. For analysis, the composites were dried at $37^{\circ} \mathrm{C}$ and annealed for $1 \mathrm{~h}$ at $900^{\circ} \mathrm{C}$.

Sample N2: HA-AG composite. Orthophosphoric acid $\mathrm{H}_{3} \mathrm{PO}_{4}(0.06 \mathrm{M})$, anhydrous calcium chloride $\mathrm{CaCl}_{2}(0.1 \mathrm{M})$, aqueous solution of sodium hydroxide $\mathrm{NaOH}(10 \mathrm{M})$ and sodium alginate (E401, MW $15 \mathrm{kDa}$, China) were used as starting materials for the HA-AG composite preparation. The composite material was synthesized by the "wet chemistry" method: 1) sodium alginate was dissolved in $100 \mathrm{ml}$ of $0.06 \mathrm{M}$ $\mathrm{H}_{3} \mathrm{PO}_{4}$ in the amount, which provides its content in the final material from 10 to $40 \mathrm{w} \%$ at $37{ }^{\circ} \mathrm{C}$. This solution was added drop by drop to the calcium chloride solution with vigorous stirring. After mixing the reactants, the suspension was treated with ultrasound. Then, $\mathrm{pH}$ value was adjusted with $10 \mathrm{M} \mathrm{NaOH}$ to 10.6 and the suspension was heated at $60{ }^{\circ} \mathrm{C}$ during $10 \mathrm{~min}$. After aging within 10 days the precipitate was thoroughly washed with the deionized water; solids were separated by centrifugation and sterilized. The degree of moisture in the obtained gel ranged from 70 to $88 \mathrm{w} \%$. The composition of solids was: HA from 60 to $90 \mathrm{w} \%$, AG from 10 to $40 \mathrm{w} \%$. The obtained samples were dried at $37{ }^{\circ} \mathrm{C}$ and annealed for $1 \mathrm{~h}$ at $900{ }^{\circ} \mathrm{C}$ for further research.

To evaluate the structure of samples - the lattice options (a, c), the average crystallite size (L, D) and microstrain $\varepsilon$ - two methods were used and com- pared: X-Ray diffraction (XRD) and transmission electron microscopy (TEM; SELMI, Sumy, Ukraine) with the electron diffraction (ED). The obtained data are shown in Table 2.

Both instrumental methods confirm the effect of the polymer component on the structural properties of HA crystallites. Thus, under the condition of synthesis of HA nanoparticles in the presence of polymer the size of crystallites decreased compared to pure HA in samples dried at $37^{\circ} \mathrm{C}$. An average size of crystallite increased after annealing and combustion of the polymer component in the HA-CS and HA-AG samples.

Fig. 5 shows the XRD patterns for the HA-CS and $\mathrm{HA}-\mathrm{AG}$ samples dried at $37^{\circ} \mathrm{C}$ and annealed at $900{ }^{\circ} \mathrm{C}$.

According to the XRD analysis, the sample 1 after annealing at $900{ }^{\circ} \mathrm{C}$ included two phases: HA (JCDPS 9-432, with $1.67 \mathrm{Ca} / \mathrm{P}$ ratio, concentration $97 \mathrm{w} \%$ ) and $\mathrm{CaO}$ (JCDPS 37-1497, concentration $3 \mathrm{w} \%)$. The presence of another phase after the temperature test indicates the nonstoichiometric output of apatite. The main factor causing a small size of crystallites and high level of microdeformations is an addition of chitosan, which, as has been shown in previous studies [55], reduces crystallinity of apatite and distorts its crystal lattice.

In the sample № 2 after annealing at $900{ }^{\circ} \mathrm{C}$ only one phase HA (JCPDS 9-432, with $1.67 \mathrm{Ca} / \mathrm{P}$ ratio) was found which indicated the stoichiometry of the initial apatite.

The nanostructures of the HA-CS and HA-AG composites were examined using TEM, as shown in our previous studies [56].

Table 2. Data of TEM and XRD analysis of structure of HA (pure), HA-CS and HA-AG composites

\begin{tabular}{|l|c|c|c|l|l|}
\hline \multirow{2}{*}{ Sample } & \multicolumn{4}{|c|}{ Dried at $37^{\circ} \mathrm{C}$} & \multicolumn{1}{|c|}{$\begin{array}{c}\text { Annealed } \\
\text { at } 900^{\circ} \mathrm{C}\end{array}$} \\
\cline { 2 - 6 } & \multicolumn{3}{|c|}{ TEM with ED } & XRD & \multicolumn{1}{|c|}{ XRD } \\
\cline { 2 - 6 } & $\mathrm{a}, \mathrm{nm}$ & $\mathrm{c}, \mathrm{nm}$ & $\mathrm{D}, \mathrm{nm}$ & $L, \mathrm{~nm}$ & \multicolumn{1}{c|}{$L, \mathrm{~nm}$} \\
\hline HA-CS & 0.949 & 0.688 & $\sim 80$ & 14.3 & 55.4 \\
HA-AG & 0.945 & 0.688 & $\sim 80$ & 24.6 & 58.6 \\
HA & 0.933 & 0.684 & $\sim 120$ & 33.2 & 49.41 \\
\hline
\end{tabular}


A)

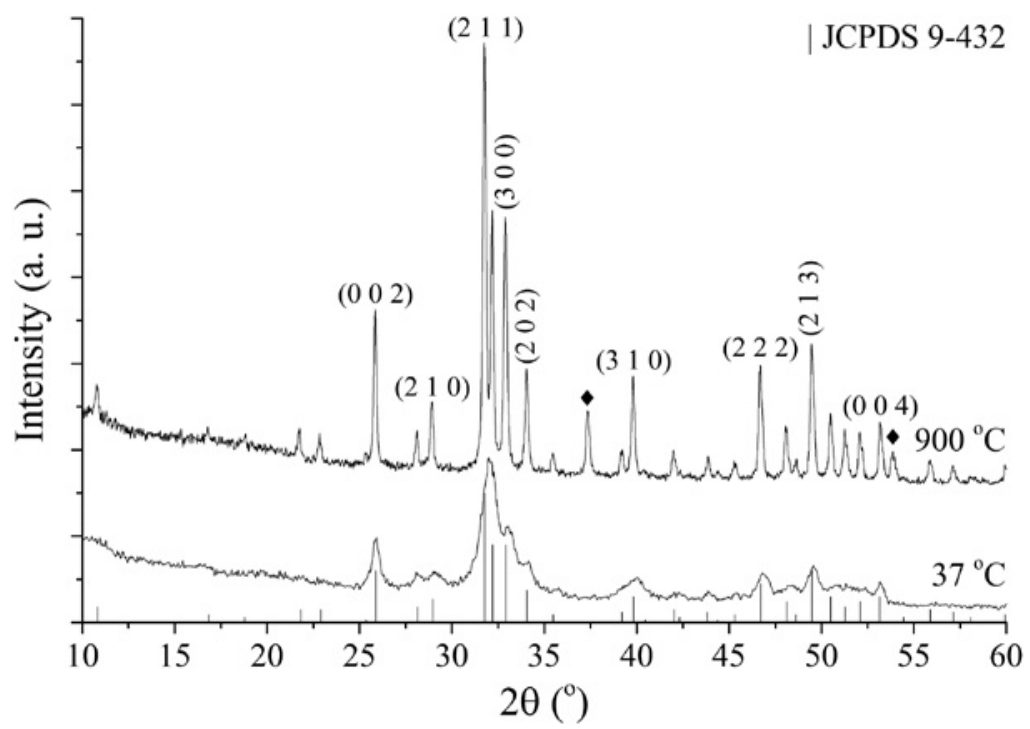

B)

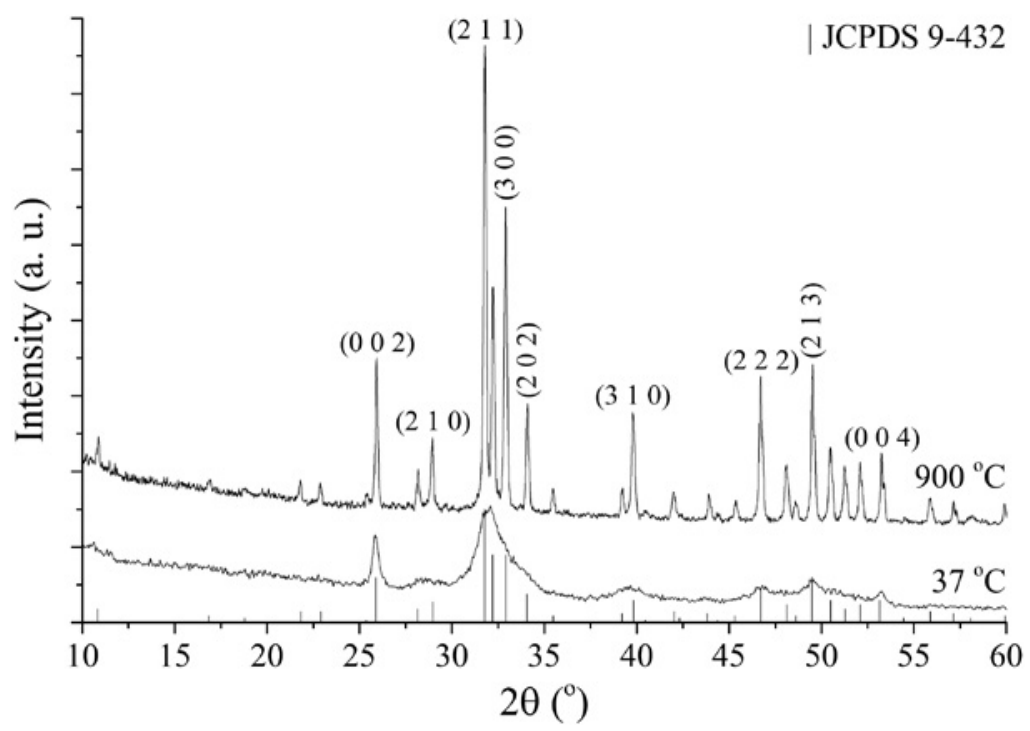

Fig. 5. A) X-ray diffraction patterns of HA-CS nanocomposites dried at $37^{\circ} \mathrm{C}$ and annealed for $1 \mathrm{~h}$ at $900{ }^{\circ} \mathrm{C}$. - assigned $\mathrm{CaO}$ phase; $B$ ) $\mathrm{X}$-ray diffraction patterns of HA-AG nanocomposites dried at $37{ }^{\circ} \mathrm{C}$ and annealed for $1 \mathrm{~h}$ at $900{ }^{\circ} \mathrm{C}$

\section{Antibacterial properties of silver-doped HA-CS composites}

One of the most important problems in modern implantology is bacterial infection. The inflammation in the implant surrounding tissue eventually leads to the loss of the implant. The use of antimicrobial films or coatings is a way for preventing inflammation. Chitosan is one of the natural polysaccharides that can form a film with antibacterial properties. There are several mechanisms of antibacterial activity of chito- san [47]. First, chitosan as a polycation forms electrostatic bonds with anionic molecules on the cell surface and thereby affects their penetrating ability [57, 58]. Second, chitosan binds to the negatively charged groups of DNA and thus inhibits the RNA synthesis $[24,59]$. Finally, the antibacterial activity of chitosan can include both mechanisms, depending on the charge density in interacting components $[24,60]$. Due to a large number of $\mathrm{OH}$ - and $\mathrm{NH}_{2}$-groups chitosan can easily form chelates with metal ions [21,61]. 
Most silver-containing antimicrobial biomaterials consist of either $\mathrm{Ag}^{+}$ions (silver salts or silver complexes) or elemental silver (Ag-nanoparticles) incorporated into organic (polymers) or inorganic (bioglasses and HA) matrices [62, 63]. The silver-loaded HA composites are obtained by ion-exchange methods (sol-gel or coprecipitation) that involve the silver substitution for calcium, resulting in a Ca-deficient hydroxyapatite. The antimicrobial response of these materials is good, but there is $\mathrm{pH}$-dependent negative rapid release of silver [64]. Silver nanoparticles have the antibacterial properties, delaying the growth of Gram-positive and Gram-negative bacteria. It is also well known that the antibacterial activity of $\mathrm{Ag}$ nanoparticles is caused not only by free $\mathrm{Ag}^{+}$ions produced from nanoparticle surface but also by the interaction of small active nanoparticles with the microorganisms cells and destruction of their membranes [65-67]. Chitosan-nanosilver-based films exhibit the excellent antibacterial activity against Escherichia coli [61]. Therefore, in the recent research [68], our group has used the termodeposition method [31] for obtaining antimicrobial $\mathrm{Ag}^{+}$-doped hydroxyapatite coatings under physiological conditions with various concentrations of silver ions and therefore different antibacterial activity. Thus, $\mathrm{HA}-\mathrm{Ag}^{+}$-coatings were created on both the chitosan- modified and non-modified Ti-6Al-4V substrates. Antibacterial properties were studied by the optical density evaluation of the E.coli ATCC 25922 bacterial suspensions (Institute of Microbiology and Immunology, National Academy of Medical Sciences of Ukraine) before and after immersing the experimental samples into these suspensions. The optical density was measured by spectrophotometry at $\mathrm{l}=540 \mathrm{~nm} \mathrm{2,24}$ and $48 \mathrm{~h}$ after the sample immersion. The bacterial cell amount was evaluated from the optical density measurements of the bacteria suspension with known concentration in CFU mL-1 (Colony Forming Units). It was found that the inclusion of $\mathrm{Ag}^{+}$-ions into the coating significantly reduced the number of bacteria in a sample. Even a stronger effect occurred for the $\mathrm{Ag}^{+}$-ions doped HA coatings, formed at a surface of the substrate with CS layer (Fig. 6).

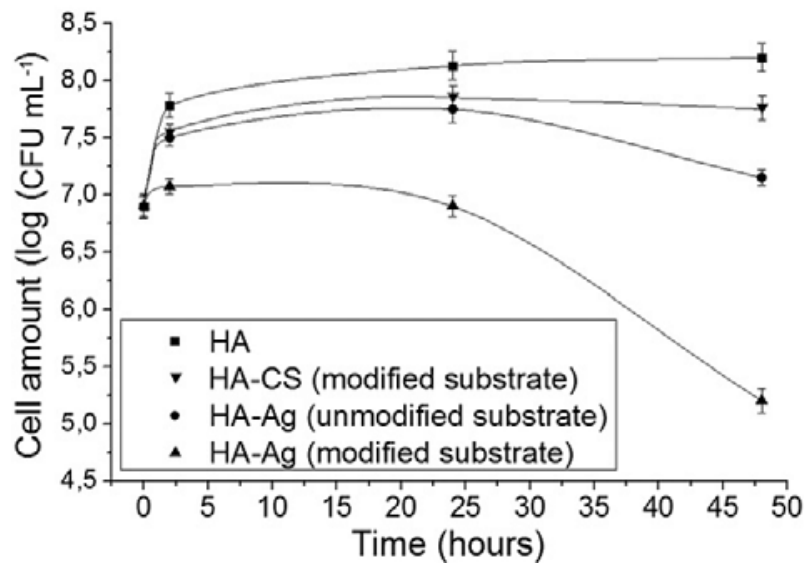

Fig. 6. Dependence of E.coli growth on the time after immersion of HA-CS (modified substrate), HA-Ag (unmodified substrate) and $\mathrm{HA}-\mathrm{Ag}$ (modified substrate) coatings in comparison with the HA coating

The proposed approach can be taken as a promising method to create antimicrobial coatings for titanium implants [68].

\section{Chitosan-biopolymer composites for drug delivery}

Regenerative medicine plays an important role in the restoring of damaged organs in vivo by the activation of stimulating factors of the organism. One of the advantages of chitosan is the ability of controlling the release of active compounds without the use of toxic organic solutions, because of its good solubility in weakly acid solutions. These circumstances led to the use of CS for the creation of drug delivery systems. For example, CS was once used for dissolving poorly soluble pharmaceuticals in the synthesis of mucoadhesive mixtures [69-71], and for enhancement of the peptides absorption] [72-74]. Nowadays, various types of systems (tablets, capsules, microspheres, nanoparticles, films, gels) are created using different methods (coating matrix, a capsule shell, emulsive cross-linking, coacervation/ precipitation, spray drying, ionic gelation, sieving method) [3]. The chosen method must be specific to the determined component in the particular case studied (particle size, thermal and chemical properties of active agents, the stability of the final pro- 
duct, etc.). The main problem in the drug delivery therapy is to provide the necessary drug concentration at the destination [75]. One of the modern approaches is the use of CaP-biopolymer scaffolds, including polysaccharides of chitosan and alginate in combination with hydroxyapatite, as above discussed. It was shown that chitosan coatings on alginate scaffolds enhance osteoblast adhesion and proliferation [46]. Additionally, improvements in the composite mechanical properties were achieved in the scaffolds containing both polymers compared to those containing separate polysaccharides [76]. For example, the effectiveness of chitosan and alginate has been shown for more prolonged and controlled release of lidocaine $\left(\mathrm{C}_{14} \mathrm{H}_{22} \mathrm{~N}_{2} \mathrm{O}\right)$, which is a local anesthetic drug, into physiological solution with phosphate buffer (PBS) [75]. According to FTIR spectroscopy, no chemical reactions have been registered between hydroxyapatite, chitosan, alginate and lidocaine. Instead, it has been shown that each polysaccharide affected crystal morphology of the drug: needle-shaped crystals of lidocaine occurred when chitosan was used as a coating, whereas the using alginate as a coating induced the formation of rectangular crystals [75].

\section{Chitosan-metal complexes}

As noted above, one of the important properties of chitosan is the formation of chelate with metal ions. Some researches prove a higher antimicrobial activity of chitosan-metal complexes compared with pure chitosan [77]. Such complexes were obtained in two stages. First, the nanoparticles of chitosan were produced by ionic gelation between chitosan and sodium tripolyphosphate $\left(\mathrm{Na}_{5} \mathrm{P}_{3} \mathrm{O}_{10}\right)$, then the obtained nanoparticles were connected ("loaded") with metal ions $\left(\mathrm{Ag}^{+}, \mathrm{Cu}^{2+}, \mathrm{Zn}^{2+}, \mathrm{Mn}^{2+}, \mathrm{Fe}^{2+}\right)$ [77]. Antibacterial activities of the metal ions doped chitosan nanoparticles, pure chitosan nanoparticles, metal ions and $1 \mathrm{w} \%$ acetic acid solution ( used as a solvent for chitosan) were evaluated by determination of the minimum inhibitory concentration (MIC) and minimum bactericidal concentration (MBC). MIC was determined by the broth dilution method as an equiv- alent to the minimum sample concentration that did not cause the visible bacteria growth in the tube, containing the bacteria suspension and experimental sample. To evaluate MBC, the bacteria suspension aliquot was transferred from each tube without visible growth on a Muller-Hinton $(\mathrm{MH})$ agar plate ( $\mathrm{MH}$ was used as a growth media) and incubated at $37{ }^{\circ} \mathrm{C}$ for $24 \mathrm{~h}$. MBC was determined as the minimum sample concentration that did not cause any bacterial growth. Antibacterial properties of the chitosan nanoparticles have been significantly improved by the metal ions addition. For example, for the $\mathrm{Cu}^{2+}$ doped CS-nanoparticles, $\mathrm{MIC}$ and $\mathrm{MBC}$ against E.coli ATCC25922, S.choleraesuis ATCC 50020 and $S$. aureus 25923 were 21-42 times lower than for pure $\mathrm{Cu}^{2+}$ ions [77]. The report states that Gramnegative bacteria are more sensitive to chitosan-metal nanoparticles, due to a high negative charge at a surface of the respective cells, on the one hand, and a positive charge of amino groups reinforced by the interaction of macromolecules with metal ions, on the other hand. However, this hypothesis must be confirmed by new experimental and theoretical quantum-chemical researches.

\section{Chitosan nanofibers}

One of the newest applications of chitosan in medicine is the development of natural methods for obtaining chitosan nanofibers [78]. Similar structures are produced by the "Nanospider" technology. The process occurs as follows. 1) In a special chamber between the cathode and anode a voltage of $60 \mathrm{kV}$ is applied. 2) As a result, at a surface of the cathode covered with a thin film of chitosan solution, a spiral flow of polymer molecules is formed (Taylor cone). 3 ) The velocity of the particles increases with the movement toward the negatively charged electrode; the diameter of individual flow reduces to nanoscale. 4) Solvent molecules are evaporated and the stretched macromolecules are drawn together, i.e. a phase transition from liquid to solid state is observed. 5) The obtained nanofibers are adsorbed to the negatively charged base plate material (any substance, a metal substrate, etc.). 
There are different physical, chemical (the type of solvent, the DD and MW parameters of chitosan, the solution homogenization without formation of macromolecular tangles, the viscosity and electrical conductivity of the cathode forming solution) and technological (the humidity in the chamber 30$50 \mathrm{w} \%$, the distance between electrodes 150 $180 \mathrm{~mm}$ ) features of this technology to vary for obtaining the chitosan nanofibers with a size of 70$200 \mathrm{~nm}$. The first attempts of application of the nanostructures, obtained by this technology, in medicine, e.g. as bandage, demonstrate a new perspective in the effective treatment of burns and similar injuries [78].

\section{Conclusion}

Chitosan characteristics considered in this review indicate a significant potential for its use as a biomaterial with the required properties (porosity, degree of biodegradation) in the applied medicine, particularly for bone regeneration. However, some extra efforts are necessary to improve the mechanical properties of chitosan-based biomaterials for the applications. Another a very significant feature of chitosan is its ability of interacting with anionic biomolecules such as growth factors, glycosaminoglycans and DNA. The binding to DNA molecules makes it possible to obtain the material suitable for the application in gene therapy. Taking into account a combination of chitosan properties (biocompatibility, antibacterial ability, the complexation with growth factors and DNA) the conclusion can be made that chitosan is a very promising candidate for tissue engineering scaffolds. However, some parameters such as molecular weight, viscosity, should be further examined to exploit the potential of this natural polysaccharide in nanomedicine.

\section{Acknowledgements}

We thank the Ukrainian Fundamental Foundation (project NU/7-2013) for funding our researches, Dr. V.G. Lugin from State technological university of Belarus for IR-studies of the apatite-biopolymer samples.

\section{REFERENCES}

1. Jamalpoor Z. Chitosan: a brief review on structure and tissue engineering application. J Appl Tissue Eng. 2014;1(1):37.

2. Croisier F, Jerome C. Chitosan-based biomaterials for tissue engineering. Eur Polym J. 2013;49(4):780-92.

3. Nikitenko P, Khrustitskaya L. Chitosan - a polymer of the future. The Science and Innovations. 2013;127(9):14-7.

4. Dash M, Chiellini F, Ottenbrite RM, Chiellini E. Chitosana versatile semi-synthetic polymer in biomedical applications. Prog Polym Sci. 2011;36(8):981-1014.

5. Di Martino A, Sittinger M, Risbud MV. Chitosan: a versatile biopolymer for orthopaedic tissue-engineering. Biomaterials. 2005;26(30):5983-90.

6. Mao JS, Cui YL, Wang XH, Sun Y, Yin YJ, Zhao HM, De Yao $K$. A preliminary study on chitosan and gelatin polyelectrolyte complex cytocompatibility by cell cycle and apoptosis analysis. Biomaterials. 2004;25(18):3973-81.

7. Jayakumar R, Menon D, Manzoor K, Nair SV, Tamura H. Biomedical applications of chitin and chitosan based nanomaterials. A short review. Carbohydr Polym. 2010;82(2): 227-32.

8. Venkatesan J, Kim SK. Chitosan composites for bone tissue engineering - an overview. Mar Drugs. 2010;8(8):2252-66.

9. Dodane V, Vilivalam VD. Pharmaceutical applications of chitosan. Pharm Sci Technol Today. 1998;1(6):246-53.

10. Xie Y, Zhou NJ, Gong YF, Zhou XJ, Chen J, Hu SJ, Lu NH, Hou $X H$. Th immune response induced by $\mathrm{H}$ pylori vaccine with chitosan as adjuvant and its relation to immune protection. World J Gastroenterol. 2007;13(10):1547-53.

11. Dorozhkin $S V$. Nanodimensional and nanocrystalline apatites and other calcium orthophosphates in biomedical engineering, biology and medicine. Materials. 2009;2(4):19752045.

12. Gomez L, Ramirez HL, Neira-Carrillo A, Villalonga $R$. Polyelectrolyte complex formation mediated immobilization of chitosan-invertase neoglycoconjugate on pectincoated chitin. Bioprocess Biosyst Eng. 2006;28(6):387-95.

13. Madihally SV, Matthew HW. Porous chitosan scaffolds for tissue engineering. Biomaterials. 1999;20(12):1133-42.

14. Pavinatto FJ, Caseli L, Oliveira ON. Chitosan in nanostructured thin films. Biomacromolecules. 2010;11(8):1897-908.

15. Takahashi T, Takayama K, Machida Y, Nagai T. Characteristics of polyion complexes of chitosan with sodium alginate and sodium polyacrylate. Int J Pharm. 1990;61(12):35-41.

16. Kim T-H, Jiang H-L, Jere D, Park I-K, Cho M-H, Nah J-W, Choi Y-J, Akaike T, Cho C-S. Chemical modification of chitosan as a gene carrier in vitro and in vivo. Prog Polym Sci. 2007;32(7):726-53.

17. Varum KM, Ottøy $M H$, Smidsrod $O$. Water-solubility of partially $\mathrm{N}$-acetylated chitosans as a function of $\mathrm{pH}$ : effect of 
chemical composition and depolymerisation. Carbohydr Polym. 1994;25(2):65-70.

18. Anthonsen $M W$, Smidsrod $O$. Hydrogen ion titration of chitosans with varying degrees of $\mathrm{N}$-acetylation by monitoring induced 1H-NMR chemical shifts. Carbohydr Polym. 1995; 26(4):303-5.

19. Payne GF, Raghavan SR. Chitosan: a soft interconnect for hierarchical assembly of nano-scale components. Soft Matter. 2007;3(5):521-7.

20. Krajewska B. Application of chitin- and chitosan-based materials for enzyme immobilizations: a review. Enzyme Microb Technol. 2004;35(2-3):126-39.

21. Guibal E. Interactions of metal ions with chitosan-based sorbents: a review. Sep Purif Technol. 2004;38(1):43-74.

22. Chen AH, Yang $C Y$, Chen $C Y$, Chen $C Y$, Chen $C W$. The chemically crosslinked metal-complexed chitosans for comparative adsorptions of $\mathrm{Cu}$ (II), $\mathrm{Zn}$ (II), Ni(II) and $\mathrm{Pb}$ (II) ions in aqueous medium. $J$ Hazard Mater. 2009;163(23):1068-75.

23. Kong $M$, Chen XG, Liu CS, Liu CG, Meng XH, Yu le J. Antibacterial mechanism of chitosan microspheres in a solid dispersing system against E. coli. Colloids Surf B Biointerfaces. 2008;65(2):197-202.

24. Chung YC, Chen $C Y$. Antibacterial characteristics and activity of acid-soluble chitosan. Bioresour Technol. 2008; 99(8):2806-14.

25. Raafat D, von Bargen $K$, Haas A, Sahl HG. Insights into the mode of action of chitosan as an antibacterial compound. Appl Environ Microbiol. 2008;74(12):3764-73.

26. Seol YJ, Lee JY, Park YJ, Lee YM, Young-Ku, Rhyu IC, Lee SJ, Han SB, Chung CP. Chitosan sponges as tissue engineering scaffolds for bone formation. Biotechnol Lett. 2004;26(13):1037-41.

27. Seeherman H, Li R, Wozney J. A review of preclinical program development for evaluating injectable carriers for osteogenic factors. J Bone Joint Surg Am. 2003;85-A Suppl 3:96-108.

28. Zhang $Y$, Zhang $M$. Synthesis and characterization of macroporous chitosan/calcium phosphate composite scaffolds for tissue engineering. J Biomed Mater Res. 2001;55(3):304-12.

29. Zhang $Y$, Zhang $M$. Calcium phosphate/chitosan composite scaffolds for controlled in vitro antibiotic drug release. J Biomed Mater Res. 2002;62(3):378-86.

30. Lian Q, Li D, Jin Z, Wang J, Li A, Wang Z, Jin Z. Fabrication and in vitro evaluation of calcium phosphate combined with chitosan fibers for scaffold structures. J Bioactive Comp Polym. 2009;24(1):113-24.

31. Sukhodub LF, Yanovska GO, Sukhodub LB, Kuznetsov VM, Stanislavov OS. Nanocomposite apatite-biopolymer materials and coatings for biomedical applications. J Nano- Electron Phys. 2014;6(1):id01001.

32. Swetha $M$, Sahithi $K$, Moorthi A, Srinivasan N, Ramasamy $K$, Selvamurugan N. Biocomposites containing natural polymers and hydroxyapatite for bone tissue engineering. Int J Biol Macromol. 2010;47(1):1-4.

33. Zhang $Y$, Zhang $M$. Three-dimensional macroporous calcium phosphate bioceramics with nested chitosan sponges for loadbearing bone implants. J Biomed Mater Res. 2002;61(1):1-8.

34. Zhang Y, Ni M, Zhang M, Ratner B. Calcium phosphatechitosan composite scaffolds for bone tissue engineering. Tissue Eng. 2003;9(2):337-45.

35. Murugan R, Ramakrishna S. Bioresorbable composite bone paste using polysaccharide based nano hydroxyapatite. Biomaterials. 2004;25(17):3829-35.

36. Wagoner Johnson AJ, Herschler BA. A review of the mechanical behavior of $\mathrm{CaP}$ and $\mathrm{CaP} /$ polymer composites for applications in bone replacement and repair. Acta Biomater. 2011;7(1):16-30.

37. Klug HP, Alexander LE. X-Ray Diffraction procedures: for polycrystalline and amorphous materials. New York: Wiley, 1974. 992 p.

38. Malesu VK, Sahoo D, Nayak PL. Chitosan-sodium alginate nanocomposites blended with cloisite $30 \mathrm{~b}$ as a novel drug delivery system for anticancer drug curcumin. Int J Appl Biol Pharm. 2011;2(3):402-11.

39. Li B, Wang Y, Jia D, Zhou Y. Gradient structural bone-like apatite induced by chitosan hydrogel via ion assembly. J Biomater Sci Polym Ed. 2011;22(4-6):505-17.

40. Amaral IF, Granja PL, Barbosa MA. Chemical modification of chitosan by phosphorylation: an XPS, FT-IR and SEM study. J Biomater Sci Polym Ed. 2005;16(12):1575-93.

41. Roeges $N P G$. A Guide to the complete interpretation of infrared spectra of organic structures. Wiley: Chichester, 1994. $340 \mathrm{p}$.

42. Tarasevich $B N$. IR spectra of major classes of organic compounds. Moscow: Lomonosov Moscow State University, 2012. 54 p.

43. Manjubala I, Scheler S, Bössert J, Jandt KD. Mineralisation of chitosan scaffolds with nano-apatite formation by double diffusion technique. Acta Biomater. 2006;2(1):75-84.

44. Rehman I, Bonfield W. Characterization of hydroxyapatite and carbonated apatite by photo acoustic FTIR spectroscopy. J Mater Sci Mater Med. 1997;8(1):1-4.

45. Nayar $S$, Sinha $A$. Systematic evolution of a porous hydroxyapatite-poly(vinylalcohol)-gelatin composite. Colloids Surf B Biointerfaces. 2004;35(1):29-32.

46. Han J, Zhou Z, Yin R, Yang D, Nie J. Alginate-chitosan/hydroxyapatite polyelectrolyte complex porous scaffolds: preparation and characterization. Int $J$ Biol Macromol. 2010;46(2):199-205.

47. Boddohi S, Moore N, Johnson PA, Kipper MJ. Polysaccharide-based polyelectrolyte complex nanoparticles from chitosan, heparin, and hyaluronan. Biomacromolecules. 2009; 10(6):1402-9.

48. Ilina AV, Varlamov VP. Chitosan-based polyelectrolyte complexes: a review. Appl Biochem Microbiol. 2005;41(1):5-11. 
49. Denuziere A, Ferrier D, Damour O, Domard A. Chitosanchondroitin sulfate and chitosan-hyaluronate polyelectrolyte complexes: biological properties. Biomaterials. 1998; 19(14):1275-85.

50. Yin YJ, Yao KD, Cheng GX, Ma JB. Properties of polyelectrolyte complex films of chitosan and gelatin. Polym Int. 1999;48(6):429-32.

51. Jiang T, Zhang Z, Zhou Y, Liu Y, Wang Z, Tong H, Shen X, Wang $Y$. Surface functionalization of titanium with chitosan/ gelatin via electrophoretic deposition: characterization and cell behavior. Biomacromolecules. 2010;11(5):1254-60.

52. Bhattarai N, Gunn J, Zhang M. Chitosan-based hydrogels for controlled, localized drug delivery. Adv Drug Deliv Rev. 2010;62(1):83-99.

53. Drury JL, Mooney DJ. Hydrogels for tissue engineering: scaffold design variables and applications. Biomaterials. 2003;24(24):4337-51.

54. Mann BK. Biologic gels in tissue engineering. Clin Plast Surg. 2003;30(4):601-9.

55. Danilchenko SN, Kalinkevich OV, Kuznetsov VN, Kalinkevich AN, Kalinichenko TG, Poddubny IN, Starikov VV, Sklyar $A M$, Sukhodub LF. Thermal transformations of the mineral component of composite biomaterials based on chitosan and apatite. Crystal Res Technol. 2010;45(7):685-91.

56. Kuznetsov VM, Sukhodub LB, Sukhodub LF. Structural and substructural features of apatite-biopolymer composites: the comparison of data obtained using X-ray diffraction and scanning electron microscopy with electron diffraction. J Nano- Electron Phys. 2014;6(4):id04039.

57. Je JY, Kim SK. Chitosan derivatives killed bacteria by disrupting the outer and inner membrane. J Agric Food Chem. 2006;54(18):6629-33.

58. Liu H, Du Y, Wang X, Sun L. Chitosan kills bacteria through cell membrane damage. Int J Food Microbiol. 2004; 95(2): 147-55.

59. Moussa SH, Tayel AA, Al-Turki AI. Evaluation of fungal chitosan as a biocontrol and antibacterial agent using fluorescence-labeling. Int J Biol Macromol. 2013;54:204-8.

60. Chung YC, Su YP, Chen CC, Jia G, Wang HL, Wu JC, Lin $J G$. Relationship between antibacterial activity of chitosan and surface characteristics of cell wall. Acta Pharmacol Sin. 2004;25(7):932-6.

61. Thomas V, Yallapu M, Mohan SB, Bajpai SK. Fabrication, characterization of chitosan. nanosilver film and its potential antibacterial application. J Biomater Sci Polym Ed. 2009;20(14):2129-44.

62. Kumar R, Münstedt $H$. Silver ion release from antimicrobial polyamide/silver composites. Biomaterials. 2005;26(14): 2081-8.

63. Alt V, Bechert T, Steinrücke P, Wagener M, Seidel P, Dingeldein E, Domann E, Schnettler R. An in vitro assessment of the antibacterial properties and cytotoxicity of nanoparticulate silver bone cement. Biomaterials. 2004;25(18):4383-91.
64. Han IH, Lee IS, Song JH, Lee MH, Park JC, Lee GH, Sun $X D$, Chung SM. Characterization of a silver-incorporated calcium phosphate film by RBS and its antimicrobial effects. Biomed Mater. 2007;2(3):S91-4.

65. Diaz M, Barba F, Miranda M, Guiti F, Torrecillas R, Moya JS. Synthesis and Antimicrobial Activity of a Silver-Hydroxyapatite Nanocomposite. J Nanomater. 2009;2009:id498505.

66. Rai M, Yadav A, Gade A. Silver nanoparticles as a new generation of antimicrobials. Biotechnol Adv. 2009;27(1):76-83.

67. Bragg PD, Rainnie DJ. The effect of silver ions on the respiratory chain of Escherichia coli. Can J Microbiol. 1974;20(6):883-9.

68. Yanovska AA, Stanislavov AS, Sukhodub LB, Kuznetsov VN, Illiashenko VYu, Danilchenko SN, Sukhodub LF. Silverdoped hydroxyapatite coatings formed on Ti-6Al-4V substrates and their characterization. Mater Sci Eng C Mater Biol Appl. 2014;36:215-20.

69. Miyazaki S, Ishii K, Nadai T. The use of chitin and chitosan as drug carriers. Chem Pharm Bull (Tokyo). 1981;29(10): 3067-9.

70. He P, Davis SS, Illum L. Chitosan microspheres prepared by spray drying. Int J Pharm. 1999;187(1):53-65.

71. Sawayanagi $Y$, Nambu $N$, Nagai T. Dissolution properties and bioavailability of phenytoin from ground mixtures with chitin or chitosan. Chem Pharm Bull (Tokyo). 1983;31(6):2064-8.

72. Illum L, Farraj NF, Davis SS. Chitosan as a novel nasal delivery system for peptide drugs. Pharm Res. 1994;11(8):1186-9.

73. Luessen HL, Lehr CM, Rentel CO, Noach ABJ, de Boer AG, Verhoef JC, Junginger HE. Bioadhesive polymers for the peroral delivery of peptide drugs. $J$ Controlled Release. 1994;29(3):329-38.

74. Artursson P, Lindmark T, Davis SS, Illum L. Effect of chitosan on the permeability of monolayers of intestinal epithelial cells (Caco-2). Pharm Res. 1994;11(9):1358-61.

75. Dubnika A, Loca D, Berzina-Cimdina L. Functionalized hydroxyapatite scaffolds coated with sodium alginate and chitosan for controlled drug delivery. Proc Estonian Acad Sci. 2012;61(3):193-9.

76. Li Z, Ramay HR, Hauch KD, Xiao D, Zhang M. Chitosanalginate hybrid scaffolds for bone tissue engineering. Biomaterials. 2005;26(18):3919-28.

77. Du WL, Niu SS, Xu YL, Xu ZR, Fan CL. Antibacterial activity of chitosan tripolyphosphate nanoparticles loaded with various metal ions. Carbohydr Polym. 2009;75(3):385-9.

78. Ifuku $S$. Chitin and chitosan nanofibers: preparation and chemical modifications. Molecules. 2014;19(11):18367-80.

\section{Хітозан-апатитні композити: синтез і властивості}

Л. Ф. Суходуб, Л. Б. Суходуб, І. В. Чорна

Мета цього короткого огляду - розгляд застосування унікального біополімеру хітозану в практичній медицині, особливо для інженерії кісткової тканини. Основне місце в статті відве- 
дено синтезу та властивостям інноваційних біоматеріалів на основі хітозану, таким як СaР-хітозан (CS-CP)-композити і хітозан-альгінатні (CS-AG)-скаффолди. У статті висвітлено фізико-хімічні властивості, спектральні характеристики і хімічні модифікації молекули хітозану. Отримані хітозан-апатитні композитні матеріали були проаналізовані з використанням методу рентгенівської дифракції для аналізу кристалічної природи їх структур. Було виявлено, що додавання хітозану до композитного матеріалу призводить до зниження кристалічності вихідного апатиту. Крім того, акцентовано увагу на антибактеріальні властивості хітозану, використанні наночастинок хітозану для отримання нановолокон і створенні системи контрольованої доставки ліків.

Кл юч ов і с л о в а: хітозан, гідроксиапатит, біокомпозити, рентгенівська дифракція.

\section{Хитозан-апатитные композиты: синтез и свойства}

Л. Ф. Суходуб, Л. Б. Суходуб, И. В. Черная

Цель этого краткого обзора - рассмотрение применения уникального биополимера хитозана в практической медицине, особенно для инженерии костной ткани. Основное место в статье отведено синтезу и свойствам инновационных биоматериалов на основе хитозана, таким как СаР-хитозан (CS-CP)композиты и хитозан-альгинатные (CS-AG)-скаффолды. В статье освещены физико-химические свойства, спектральные характеристики и химические модификации молекулы хитозана. Полученные хитозан-апатитные композитные материалы были проанализированы с использованием метода рентгеновской дифракции для анализа кристаллической природы их структур. Было обнаружено, что добавление хитозана к композитному материалу приводило к снижению кристалличности исходного апатита. Кроме того, акцентировано внимание на антибактериальных свойствах хитозана, использовании наночастиц хитозана для получения нановолокон и создании систем контролируемой доставки лекарств.

Кл юч е в ы е с л о в а: хитозан, гидроксиапатит, биокомпозиты, рентгеновская дифракция.

Received 21.02.2016 